\title{
Badgers as a potential source of bovine tuberculosis - first studies in Poland
}

\author{
Marek Lipiec ${ }^{1, A, C-D, F}$, Krzysztof Nowakowski ${ }^{2, B}$, Łukasz Radulski ${ }^{1, B-C}$, Wojciech Iwaniak ${ }^{1, A, E}$, \\ Agnieszka Ważna ${ }^{2, A-B}$ \\ ${ }^{1}$ National Veterinary Research Institute, Pulawy, Poland \\ 2 University of Zielona Góra, Department of Zoology, Zielona Góra, Poland \\ A - Research concept and design, B - Collection and/or assembly of data, C - Data analysis and interpretation, \\ $D$ - Writing the article, E - Critical revision of the article, F - Final approval of article
}

Lipiec M, Nowakowski K, Radulski Ł, Iwaniak W, Ważna A. Badgers as a potential source of bovine tuberculosis - first studies in Poland. Ann Agric Environ Med. 2018; 25(3): 409-410. doi: 10.26444/aaem/80984

\section{Abstract}

Since 2009, Poland has been recognized as a country officially free of bovine tuberculosis (BTB). However, new outbreaks are each year quoted. In many countries it has been shown that badgers (Meles meles) are a vector of Mycobacterium bovis/ caprae (M.bovis/caprae) and a source of bovine tuberculosis for many domestical species, mainly for cattle. The aim of the presented study was to determine, for the first time in Poland, the occurrence of tuberculosis in badgers in areas where the disease occurs in cattle. Tissue samples were examined by classical microbiology methods, mycobacteria growth indicator tube (MGIT), and real time PCR. A total of 155 samples from 31 badgers were examined. In any case Mycobacterium bovis/caprae infection has not been diagnosed. This indicates that badgers probably are not a vector of bovine tuberculosis in Poland.

\section{Key words}

badgers, bovine tuberculosis, Poland

\section{INTRODUCTION}

Since 2009, Poland has been recognized as a country officially free of bovine tuberculosis (BTB). However, in Poland, in the years 2014-2016, there were 16-20 outbreaks of tuberculosis every year, in different parts of the country. The study was conducted in one of the regions with an increased number of BTB outbreaks in the western part of the country. Each year, due to tuberculosis, 200-500 animals from cattle herds are considered to be infected after positive results of single or comparative tuberculin test of which about $60 \%$ are confirmed as BTB infected in laboratory tests [1]).

Due to the possibility of BTB spread current monitoring of susceptible wild animal species is conducted. In Poland, the study of badgers for BTB has not been carrying out before and the scale of the problem has not been recognized yet. Badgers are strictly protected species in Poland. Acquisition of samples for research is difficult and possible only in case of natural death or traffic accidents. In the presented studies samples from 31 badgers were obtained after their death in car accidents. The aim of this study was to assess the prevalence of BTB in badgers in west region of Poland with high number of BTB outbreaks in cattle. In this area (about $200 \mathrm{~km}^{2}$ ) in 2014-2016 years 8 outbreaks of BTB in cattle were detected.

\section{MATERIAL AND METHODS}

Samples of mesenteric and bronchial lymph nodes, lungs, liver and spleen were received from 31 badgers collected in 2014-

Address for correspondence: Marek Lipiec, National Veterinary Research Institute, Pulawy, Poland, 24-100 Puławy, Partyzantów 57, Poland

E-mail: mlipiec@piwet.pulawy.pl

Received: 18.09.2017; accepted: 05.12.2017; first published: 23.02.2018
2016 years in mentioned area (Trzciel forest district, border of the lubuskie and wielkopolskie voivodships). Tissue samples were homogenized and decontamined in $5.0 \%$ oxalic acid and then washed twice with a $0.85 \% \mathrm{NaCl}$ (saline), according to the Instruction of the Central Veterinary Officer. The sediments were used for direct microscopical examination, culture and for MGIT and PCR tests. The smears were prepared from tissues as well as sediments and were stained using Ziehl- Neelsen (ZN) method. The sediments were inoculated onto three Stonebrink (S), Petragnani (P) and Lowenstein- Jensen (L.J) slants. All slants were incubated at $37^{\circ} \mathrm{C}$ for $4-6$ weeks, with weekly readings. Simultaneously samples were tested in Mycobacteria Growth Indicator Tube (MGIT) system. All samples were prepared with MycoPrep kit (Becton Dickinson) used for the preparation of specimens containing mycobacteria, according to the manufacturer's recommendations. Pre-prepared samples were incubated for 6 weeks in MGIT 320 incubator. In real time PCR Blood and Tissue Qiagen kit and Rotor Gene thermocycler were used. For identification of potentially isolated strains GenoType Mycobacterium CM (for common mycobacteria) and AS (for additional species), Hain Lifescience, Germany, and spoligotyping tests were prepared.

\section{RESULTS AND DISCUSSION}

A total of 155 samples from 31 badgers were examined. In studies of the organs no anatomo pathological changes have been observed. In Ziehl-Nielsen's staining in any cases acid-resistant bacilli have not been found as well as in MGIT system. Finally in any case M. bovis/caprae or atypical mycobacteria infection have not been diagnosed.

Badgers are the largest Polish representative of the weasel family that inhabits the territory of the whole country. The size of the national population oscillates within 50,000 
individuals at a density of 1.3 to 5.9 individuals $/ 10 \mathrm{~km}^{2}$. Badgers are usually wild predators. In many countries, including Poland, this species has artificially adapted to changing living conditions, with their diet and behavior. From the forest areas the badgers moved to urban areas, abandoned buildings, backyard gardens and pastures considered as the most common source of BTB in wild animals in Europe [2]. The role of badgers in the spread of bovine tuberculosis in different European countries is variable. Countries with a particularly high degree of isolation M.bovis/caprae from badgers are England, Wales, Ireland, France and Spain $[3,4$, $5,6]$. Currently in Spain, wildlife monitoring is ongoing and the positive rate among the badgers between 2006 and 2013 is estimated at $12-15 \%$. In Portugal, a study was conducted to determine the frequency of $M$. bovis occurrence in 11 species of wild animals. The results showed high prevalence of $M$. bovis in wild boars (21.4\%), red foxes (26.9\%), red deer (38.3\%) and mongooses (20.0\%) [7]. In Poland up to this time BTB in wild species has been identified only in wild boars (Sus scrofa) and European bison (Bison bonassus) [8].

In many countries the results of the study indicate the indisputable link between BTB infected badgers and cattle herds within a radius of $1 \mathrm{~km}$ from the site of the badgers shootings [4]. The problem of maintaining a permanent reservoir of $M$. bovis among wild animals is noticeable throughout the world. Proof of this thesis may be the result of New Zealand research, where the possums became the main reservoir of BTB [9]. In the Polish conditions the badgers habitat and the area of their feeding still remain in forest areas, with minimal contact with cattle. It seems that this is the main cause of the lack of transmission of $M$. bovis/caprae between badgers and other species of domestic animals, mainly cattle. Similar results were obtained in Slovenia, where M. bovis was not found in any of the tested badgers, and a positive result was found only in fallow deer (Dama dama) [10].

In summary the present studies indicate that badgers not represent $M$. bovis/caprae reservoir in western part of Poland.
It is a strictly protected species of relatively small density. This does not oblige the badgers to seek new habitats and feeding areas. It means that BTB reservoir among wild animals in Poland remains wild boars and European bisons.

\section{REFERENCES}

1. Krajewska M, Lipiec M, Zabost A, Augustynowicz-Kopeć E, Szulowski K. Bovine Tuberculosis in a Wild Boar (Sus scrofa) in Poland. J Wildlife Dis. 2014; 50(4): 1001-1002.

2. O'Hagan MJH, Matthews DI, Laird C, McDowell SWJ. Herd-level risk factors for bovine tuberculosis and adoption of related biosecurity measures in Northern Ireland: A case-control study. Vet J. 2016; 213(3): 26-32.

3. Balseiro A, Rodríguez O, González-Quirós P, Merediz I, Sevilla IA, Davé D et al. Infection of Eurasian badgers (Meles meles) with Mycobacterium bovis and Mycobacterium avium complex in Spain. Vet J. 2011; 190(2): 21-25.

4. Byrne AW, Kenny K, Fogarty U, O’Keeffe JJ, More SJ, McGratha G et al. Spatial and temporal analyses of metrics of tuberculosis infection in badgers (Meles meles) from the Republic of Ireland: Trends in apparent prevalence. Prev Vet Med. 2015; 122(3): 345-354.

5. Rivière J, Strat YL, Dufour B, Hendrikx P. Sensitivity of bovine tuberculosis surveillance in wildlife in France: a scenario tree approach. PLoS One 2015; 10(10): doi: 10.1371/journal.pone.0141884.

6. Smith CM, Downs SH, Mitchell A, Hayward1 AC, Fry H, Le Comber SC. Spatial targeting for bovine tuberculosis control: can the locations of infected cattle be used to find infected badgers? 2015; 10(11): doi: 10.1371/journal.pone.0142710.

7. Matos AC, Figueira L, Martins MH, Pinto ML, Matos M, Coelho AC. New insights into Mycobacterium bovis prevalence in wild mammals in Portugal. Transbound Emerg Dis. 2016; 63(5): 313-322.

8. Krajewska M, Zabost A, Welz M, Lipiec M, Orłowska B, Anusz K et al. Transmission of Mycobacterium caprae in a herd of European bison in the Bieszczady Mountains, Southern Poland. Eur J Wildlife Res. 2015; 61(2): 429-433.

9. Tait P, Saunders C, Nugent, G, Rutherford P. Valuing conservation benefits of disease control in wildlife: A choice experiment approach to bovine tuberculosis management in New Zealand's native forests. J Environ Manage. 2017; 189(5): 142-149.

10. Pate M, Zajc U, Kušar D, Žele D, Vengušt G, Pirš T et al. Mycobacterium spp. in wild game in Slovenia. Vet J. 2016; 208(2): 93-95. 